\title{
Belajar Melalui Musik Dengan Menerapkan Metode Orff
}

\author{
Ridwan $^{1)}$, Hayani Wulandari' ${ }^{2)}$, Dhea Ardiyanti ${ }^{3)}$ \\ ${ }^{1}$ Universitas Pendidikan Indonesia \\ Email : ridwansimon@student.upi.edu \\ ${ }^{2}$ Universitas Pendidikan Indonesia \\ Email : hayaniwulandari@upi.edu \\ ${ }^{3}$ Universitas Pendidikan Indonesia \\ Email : dheaardiyanti@student.upi.edu \\ DOI: $10.31849 /$ paud-lectura.v\%vi\%i.4844
}

Received 30 Agustus 2020, Accepted 29 September 2020, Published 1 Oktober 2020

\begin{abstract}
Abstrak
Artikel ini berfokus pada penanaman belajar melalui musik dengan menggunakan metode orff bagi guru maupun calon guru Pendidikan Anak Usia Dini (PAUD). Melalui metode ini, rasa musikalitas anak dapat ditumbuhkan dengan melalui kegiatan-kegiatan dasar seperti bernyanyi, menari, beracting dan memainkan alat musik yang dapat dilakukan dengan memanfaatkan barang-barang yang ada dalam kehidupan sehari-hari. Penelitian ini menggunakan metode eksperimen dengan desain pre-eksperimen one-shot case study dengan hasil dianalisis secara deskriptif. Penelitian ini dilaksanakan melalui kegiatan webinar dengan peserta guru dan calon guru Pendidikan Anak Usia Dini (PAUD). Tujuan dari penelitian ini untuk memberikan gambaran dengan jelas kepada para pendidik maupun calon pendidik mengenai pelaksanaan pembelajaran melalui musik yang kreatif pada anak usia dini melalui penggunaan metode Orff. Memiliki pemahaman akan metode Orff ini sangat diperlukan baik itu secara teoritis maupun praktis sehingga guru dan calon guru tidak hanya dapat meningkatkan pengetahuan mereka, akan tetapi dapat mengaplikasikan pembelajaran yang kreatif, inovatif dan menarik pada Pendidikan Anak Usia Dini (PAUD) tentunya tetap disesuaikan dengan karakteristik anak. Hasilnya menunjukan bahwa para peserta yang terdiri dari guru dan calon guru PAUD dapat mampu mengaplikasikan metode Orff ini dalam kegiatan pembelajaran yang terukur ketika memainkan alat musik sederhana secara bersamasama.
\end{abstract}

Kata Kunci : Musik, Metode Orff, Anak Usia Dini

\begin{abstract}
This article focuses on cultivating learning through music using the orff method for teachers and prospective Early Childhood Education (PAUD) teachers. Through this method, a child's sense of musicality can be cultivated through basic activities such as singing, dancing, acting and playing musical instruments that can be done by utilizing items in everyday life. This study used an experimental method with a one-shot case study pre-experimental design with the results analyzed descriptively. This research was carried out through a webinar with participating teachers and prospective Early Childhood Education (PAUD) teachers. The purpose of this study is to provide a clear description to educators and prospective educators about the implementation of
\end{abstract}


learning through creative music in early childhood through the use of the Orff method. Having an understanding of the Orff method is very necessary both theoretically and practically so that teachers and prospective teachers can not only increase their knowledge, but can apply creative, innovative and interesting learning in Early Childhood Education (PAUD), of course, still adjusted to the characteristics. child. The results showed that the participants, consisting of teachers and prospective PAUD teachers, were able to apply the Orff method in measurable learning activities when playing a simple musical instrument together.

Keywords : Music, Orff Method, Early Childhood

\section{PENDAHULUAN}

Seni musik erat kaitannya dngan bunyi dan nada. Terdapat beberapa metode pembelajaran musik untuk anak usia dini yang digunakan sebagai upaya dalam mengingat nada. Metode tersebut meliputi metode Orff, metode Dalcroze, dan metode Kodaly. Metode Orff merupakan metode pembelajaran musik pada anak usia dini dengan melibatkan pikiran dan tubuh melalui kegiatan menyanyi, menari, acting maupun penggunaan instrument perkusi. Terdapat beberapa penelitian terkait dengan penerapan metode Orff dalam pembelajaran musik, diantaranya yaitu penelitian yang dilakukan oleh Gustina (2019) dengan judul "Pendekatan OrffSchulwerk bagi calon guru musik di taman kanak-kanak". Penelitian tersebut menggambarkan mengenai pentingnya pemahaman akan pendekatan Orff yang harus dimiliki setiap calon guru. Penelitian lain yang dilakukan oleh Lestari (2015) dengan judul "Penerapan Metode Carl Orff Untuk Pembelajaran Musik Dalam Drumband Sebagai Upaya Meningkatkan Keaktivan Dan Kreativitas Siswa Kelompok B Tk Sinar Melati Sleman". Penelitian tersebut menyatakan bahwa melalui penggunaan metode Carl Orff keaktifan dan kreatifitas siswa terlihat meningkat yang dilihat dari indikator penilaian perkembangan siswa.

Pada tingkat satuan Pendidikan Anak Usia Dini (PAUD), musik merupakan bagian dari kegiatan pembelajaran sehari-hari. Musik dengan anak usia dini merupakan satu kesatuan yang utuh tidak dapat dipisahkan, karena pada dasarnya musik termasuk bagian dari perumbuhan dan perkembangan anak. Selaras akan hal itu Safarina (Rizky \& Putri, 2012; Sari et al., 2016) mengungkapkan bahwa musik memiliki peranan yang cukup penting dalam kehidupan peserta didik. Melalui musik peserta didik dapat terlatih untuk mengembangkan kreativitas, mengembangkan sensitivitas terhadap bunyi,meningkatkan rasa keindahan, mengungkapkan ekspresi, melatih disiplin, konsentrasi dan kepekaan terhadap lingkungan.

Kedekatan peserta didik dengan musik, menjadikan musik tersebut digunakan sebagai media pembelajaran. Pada beberapa fenomena yang terjadi, terlihat dalam pelaksanaa penggunaan musik sebagai media pembelajaran masih terlihat kurang tepat. Hal tersebut dipengaruhi oleh beberapa factor, yang 
salah satunya yaitu latar belakang pendidik yang bukan dari pendidikan musik. Akibatnya, pembelajaran musik dilakukan dengan menggunakan lagulagu yang umum dikenal oleh peserta didik, hanya saja syair lagu diganti dan sesuaikan dengan tema pembelajaran yang digunakan. Hal itu selaras dengan hasil penelitian yang dilakukan Wadiyo \& Utomo (2018) dengan judul penelitia "Pengembangan Materi Ajar Seni Budaya Sub Materi Musik pada Sekolah Umum Jenjang Pendidikan Dasar".

Salah satu cara mengantisipasi fenomena yang ada yaitu dapat dilakukan dengan menggunakan metode pembelajaran yang lebih berpusat pada kreatifitas yang tentunya sesuai dengan karakteristik anak usia dini. Menurut Melalatoa (1989; Ulucay, 2019; W Wadiyo, 2015) pembelajaran termasuk dalam bidang seni perlu disesuaikan dengan pemahaman anak dan karakteristik dari setiap individunya sehingga pesan yang terkandung dalam seni dapat dipahami oleh anak. Metode pembelajaran tersebut tentunya metode Orff yang dipelopori oleh komonis Jerman bernama Carl Orff beserta rekannya Gunild Keetman. Melalui metode ini, pendidik dapat menggali kreatifitas anak dibidang musik dengan keterlibatan anak secara aktif dalam kegiatan pembelajaran (Sumaryanto F. \& Utomo, 2015). Selaras akan hal tersebut, penelitian yang dilakukan Yosep (2004) yang menyatakan bahwa pemmbelajaran melalui musik perlu didukung dengan kegiatan yang dilakukan secara alamiah, menyenangkan, serta dalam waktu yang singkat akan tetapi penuh makna.

Berdasarkan fenomena dan penelitian yang terkait, Peneliti mencoba mengungkapkan dan memperkenalkan mengenai metode Orff kepada pendidik dan para calon pendidik anak usia dini. Penelitian ini lebih terfokuskan pada pelaksanaan pembelajaran musik dengan menggunakan metode Orf pada anak usia dini, serta terkait juga manfaat dari penerapan pembelajaran menggunakan metode Orf. Tujuan dari penelitian ini yaitu agar dapat memberikan gambaran dengan jelas kepada para pendidik maupun calon pendidik mengenai pelaksanaan pembelajaran musik yang kreatif pada anak usia dini melalui penggunaan metode Orf.

\section{METODE PENELITIAN}

Metode penelitian yang digunakan adalah metode eksperimen dengan desain pre-eksperimen one-shot case study. Penelitian ini dilaksanakan melalui kegiatan webinar dengan peserta guru dan calon guru Pendidikan Anak Usia Dini (PAUD). Tujuan dari penggunaan metode penelitian ini untuk mengetahui penerapan belajar melalui musik dengan menggunakan metode Orff, dengan cara memberikan perlakuan berupa penanaman materi kepada guru dan calon guru Pendidikan Anak Usia Dini (PAUD) yang kemudian diobservasi setelah pemberian materi dengan melihat kemampuan guru dalam memainkan alat musik secara bersama-sama. 
Analisis data pada penelitian ini dilakukan secara deskriptif sehingga tergambarakan pelaksanaan dan hasilnya terhadap guru dan calon guru sehingga bisa melakukan kegiatan belajar melalui musik dengan menerapkan metode Orff.

Berikut ini gambaran mengenai paradigma penelitian pre-eksperimen one-shot case study:

\section{$\mathrm{XO}$}

Keterangan :

$\mathrm{X}=$ Treatment yang diberikan

$\mathrm{O}=$ Observasi

\section{HASIL DAN PEMBAHASAN}

Penelitian ini diawali dengan pemberian penjelasan mengenai musik. Pada hakikatnya musik bagian dari seni yang menggunakan bunyi sebagai media penciptaannya dengan memperhatikan syarat-syarat tertentu. Musik adalah suatu hasil karya seni bunyi dalam bentuk lagu yang terdiri dari unsur-unsur musik yaitu irama, melodi, harmoni, bentuk dan struktur lagu serta ekspresi. Musik dapat digunakan untuk stimulasi dalam kegiatan pendidikan karena pada dasarnya musik sangat berpengaruh terhadap perkembangan keseimbangan rasional, emosional, intelektual serta kesadaran akan nilai estetis (Udi Utomo, 2004). Hal tersebut selaras dengan beberapa hasil penelitian yang tertuang dalam Bulletin of the Council for Research in Music Education (Halimah, 2016; Udi Utomo, 2004) beberapa diantaranya meliputi : 1)
Pendidikan musik terhadap perkembangan anak dalam bahasa termasuk kecepatan membaca, 2) Melalui bermusik dapat memperkaya pengalaman anak terutama yang berkaitan dengan ekspresi, 3) Melalui bermusik dapat meningkatkan kreativitas peserta didik, serta 5) Melalui pendidikan musik dapat mendorong peserta didik dalam aspek penyesuaian diri dengan lingkungannya. Berdasarkan penelitian yang dilakukan Wicaksono \& Utomo (2017) yang menjadi daya tarik sebuah lagu dikalangan peserta didik yaitu karakteristik melodi lagu yang menarik, isi syair yang sesuai dengan pengetahuan anak, isi lagu yang sesuai dengan pengalaman anak serta perlu adanya stimulus yang bersamaan dengan lagu. Melalui kegiatan bernyanyi juga dapat memberikan kebebasan kepada anak untuk berekspresi melalui suara dan juga gerak tubuhnya (Wadiyo Wadiyo \& Haryono, 2016; Wadiyo Wadiyo \& Utomo, 2018). Selaras akan hal itu sesuai dengan karakteristik lagu untuk anak usia dini yang berdasarkan pada pendapat Kamtini dan Tanjung (2005) bahwa karakteristik lagu bagi anak usia dini yaitu lagu dan nyanyian hendaknya sesuai dengan kebutuhan dan perkembangan anak, lagu dapat memberikan kesempatan pada anak untuk berfikir kreatif, lagu mengandung syair yang sesuai dengan tema dan mengandung pesan yang bermanfaat untuk anak, syair dalam lagu dapat dipahami oleh anak, dan lagu dapat 
memberikan pada anak untuk bergerak sambil bernyanyi.

Musik bukan hanya berkaitan dengan sebuah lagu, suara alam sekalipun dapat disebut sebagai musik karena didalamnya terkandung 3 unsur/elemen musik. Menurut Idris (Idris, 2014; Solin et al., 2019) kecerdasan musik merupakan kecerdasan yang paling dekat dengan manusia seperti halnya detak jantung dan denyut nadi. Ketiga elemen musik yang meliputi irama, melodi dan harmoni, tidak dapat dipisahkan satu dan yang lainnya karena ketiga unsur tersebut memiliki peranan penting dalam upaya membentuk suara musik yang baik. Ketika salah satu elemen musik tidak terpenuhi, maka hasil dari suatu karya musik menjadi terasa semu. Menurut Fitroh et al., (2016) musik mengandung tiga komponen yang dapat mempengaruhi manusia yaitu meliputi beat yang dapat mempengaruhi garakan, ritme yang dapat mempengaruhi jiwa, dan harmoni yang dapat mempengaruhi roh manusia.

Irama atau ritme merupakan pengulangan bunyi berdasarkan pada pola tertentu dalam sebuah lagu. Hal tersebut yang menjadikan sebuah lagu bernilai estetis. Menurut Jamalus (1988 : 7) ritme merupakan urutan gerak sehingga menjadi unsur dalam musik dan tari. Terbentuknya irama atau ritme dalam musik berasal dari perpaduan anatara bunyi dengan diam serta dipengaruhi oleh lamanya waktu atau panjang pendeknya, membentuk pola irama, dan gerakan yang sesuai dengan pola birama. Jamlaus (1988 : 56) juga menyatakan bahwa irama dalam musik terkait dengan panjang-pendeknya notserta berat dan ringannya aksen (tekanan) pada not. Hal tersebut menyatakan bahwa keteraturan dalam bermusik akan berdampak pada musik yang dihasilkan menjadi lebih indah.

Tempo pada irama musik terlihat teratur dan terdiri dari beberapa jenis. Ketukan-ketukan pada irama dapat lebih kuat, lebih lama, lebih pendek maupun lebih pelan dari yang lainnya. Kualitas dari aksen, tempo, birama dan ketukan perlu disesuaikan dengan karakteristik anak sehingga akan tercermin pada lagu yang akan dihasilkan. Pola ritme dengan 2/4 akan mnghasilkan kesan yang dinamis sehingga berdampak pada gerakan menjadi lebih aktif. Hal yang berbeda pada musik yang bepola ritme 4/4 yang memberikan kesan badan dan torso menjadi lebih tenang. Gerakan badan yang dihasilkannya juga cenderung lebih menghayati alur gerakannya.

Berkaitan dengan hal tersebut dapat dilakukan melalui metode Orff. Metode ini lebih berpusat kepada eksplorasi ruang bunyi dan bentuk. Hal tersebut berarti bahwa metode orf merupakan metode pengenalan hal-hal yang berkaitan dengan musik yang dapat terapkan pada anak-anak dengan melibatkan pikiran dan tubuh mereka melalui kegitan menyanyi, menari acting dan penggunaan instrument perkusi. Metode orf ini dalam pelaksanaannya menyajikan pembelajaran melalui kegiatan bermain 
dalam upaya menstimulus anak untuk dapat belajar sesuai dengan tahapan pemahaman mereka, sehingga pada prosesnya lebih menekankan pada improvisasi, komposisi dan rasa permainan alami. Hal tersebut selaras dengan pendapat Konnie K Saliba (Cary, 2012) "Orff-schulwerk can be defined as a pedagogy to organize elements of music for children through speaking, singing, playing, and dancing." Seperti yang terlihat pada gambar skema di bawah ini :

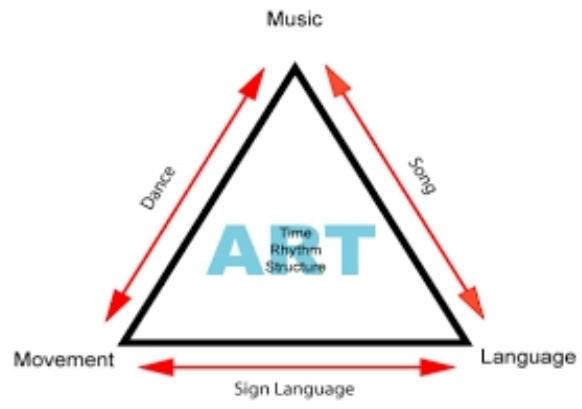

Gambar 1. Gagasan Metode Orff

(Sumber : Cary, 2012)

Berdasarkan skema di atas, tergambarkan bahwa proses pelaksanaan metode orff melibatkan kegiatan bernyanyi, menari, dan memainkan instrument yang bernada maupun yang tidak bernada dan ucapan sehingga dapat terciptanya musik yang aktif. Pada kenyataannya, beberapa kegiatan tersebut sering dilakukan oleh para guru PAUD dalam kegiatan pembelajarannya. Sebagai contoh kegiatan bernyanyi yang melibatkan tubuh dan pikiran anak salah satunya melalui bernyanyi lagu perkenalan yang diterapkan oleh guru di sekolahnya. Melalui kegiatan bernyanyi lagu tersebut, secara tidak langsung anak akan terlatih berbicara. Menurut Rasyid
(2010 : 148) lagu yang baik untuk anak yaitu lagu yang syair dan kalimatnya tidak terlalu panjang, mudah dihafal oleh anak, ada misi pendidikan, sesuai karakter dan dunia anak, nada yang diajarkan mudah dikuasai oleh anak.

Langkah kedua berkaitan dengan menari. Hal ini berkaitan dengan gerakan mengikuti irama yang lebih dikenal dengan kegiatan gerak dan lagu. Sebagai contoh lagu yang berkaitan dengan pohon. Ketika menyanyikan lagu tersebut, anak-anak dapat distimulus untuk melakukan gerakan yang sesuai dengan lagu. Melalui kegiatan bernyanyi lagu pohon ini secara tidak langsung anak dapat membangun pemahamannya yang bekaitan dengan karakteristik pohon, ketika tertiup angin, dan anak juga secara tidak langsung dapat mempelajari arah. Berkaitan dengan lagu pohon ini, dapat diaplikasikan pada pembelajaran di PAUD berdasarkan tema pembelajaran tanaman.

Berdasarkan hal tersebut, melalui gerak dan lagu dapat menambahah pemahaman dan kosakata anak. Selaras dengan penelitian yang dilakukan Arwati \& Fadillah (2019) dengan judul "Pengaruh gerak dan lagu (music and movement) terhadap peningkatan kosakata bahasa inggris pada anak usia 5-6 tahun di PAUD kasih ibu". Penelitian tersebut menyatakan bahwa melalui metode gerak dan lagu kosakata anak terlihat meningkat terutama dalam bahasa inggris.

Ketiga yaitu melalui acting. Ketika sedang mendongeng, ekspresi 
sangat diperlukan dan dari ekspresi tersebut akan terlihat beberapa penekanan dan intonasi yang jelas. Hal ini dapat dilakukan dengan kegiatan bercerita di depan kelas yang dilakukan oleh guru. Peserta didik dapat diikutsertakan dengan memilih instrument untuk mewakili setiap kata atau karakter dalam sebuah cerita yang dibacakan hingga akhirnya setiap peserta didik diberi kesempatan untuk dapat memerankan cerita.

Keempat yaitu melalui bermain musik. Belajar memainkan musik bukan berarti menuntut peserta didik menjadi seorang seniman, akan tetapi melalui musik dapat meningkatkan rasa estetis dan kepekaan peserta didik terhadap musik. Pada dasarnya, bermain musik bukan hanya berkaitan dengan penggunaan berbagai alat musik modern seperti halnya pianika, dll. Perkusi dapat digunakan sebagai salah satu media dalam bermusik. Berdasarkan kelompoknya, perkusi termasuk sebagai musik idiofone yang berarti bahwa suara yang dihasilkan berasal dari pukulan benda dengan benda lain. Musik perkusi juga tidak hanya dapat dimainkan dengan alat musik yang sudah terbentuk seperti drum, djembe dan lain sebagainya. Memainkan musik perkusi dapat dilakukan dengan memanfaatkan barang-barang yang ada dalam kehidupan sehari-hari. Beberapa diantaranya yaitu dengan drum kaleng, ember, gelas dan lain-lain. Melalui penggunaan alat musik perkusi akan memberikan pengalaman pada anak serta menunjang aktivitas yang berkaitan dengan unsur-unsur musik (Yetti \& Khairiah, 2017). Berkenaan dengan teknik dasar permainan musik perkusi dilakukan dengan :

a. Single stroke

Single stroke merupakan teknik pukulan secara bergantian antara tangan kanan dan tangan kiri. Teknik pukulan ini dilakukan dengan dengan tetap memperhatikan tempo sebagai acuan cepat lambatnya pukulan. Pada teknik ini dapat juga dilatih tempo pukulan mulai dari lambat hingga cepat ataupun sebaliknya. Untuk lebih jelas, teknik pukulan ini dapat dilihat dalam notasi musik sebagai berikut :

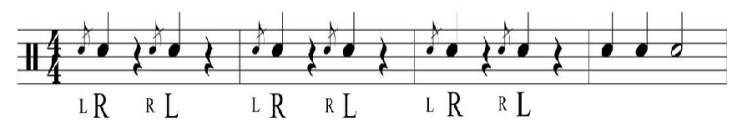

\section{Gambar 2. Notasi Musik Teknik Pukulan Single Stroke}

b. Double stroke

Teknik double stroke ini saa halnya dengan teknik pukulan single stroke, yang membedakan hanyalah setiap tangan masing-masing melakukan dua pukulan. Apabila dalam notasi terlihat sebagai berikut :

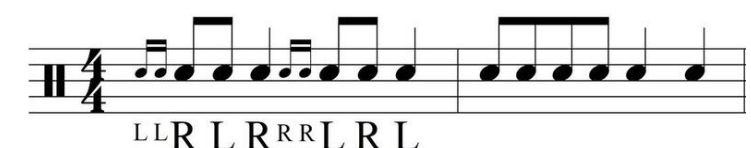

\section{Gambar 3. Notasi Musik Teknik Pukulan Double Stroke}

\section{c. Triplet}

Teknik triplet merukan teknik memukul dengan menyilangkan pola ketukan pada masing-masing tangan. 
Teknk pukulan ini berganti-ganti antara tangan kanan dan tangan kiri dengan msing-masing tangan memukul satu kali. Apabila dalam sebuah notasi dapat terlihat sebagai berikut :

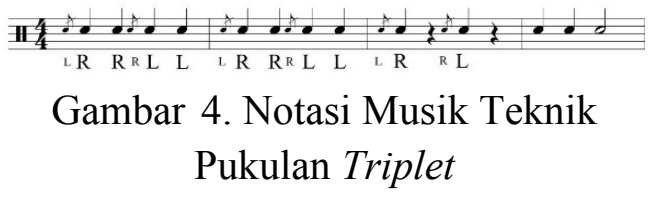

\section{d. Paradiddle}

Teknik ini dilakukan dengan mengacak pola ketukan. Teknik ini biasa digunakan untuk mengefektifkan teknik sticking pada perkusi. Apabila dalam sebuah notasi terlihat sebgai berikut :

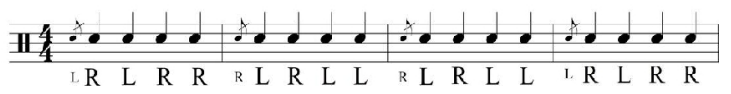

Gambar 5. Notasi Musik Teknik Pukulan Paradiddle

Barang-barang bekas tak terpakai tersebut ditabuh berdasarkan tabuhan yang beraturan sehingga mengahsilkan harmoni musik yang indah dan tidak kalah dengan alat musik yang sudah ada. Selain meningkatkan rasa musikalitas melalui alat-alat nonkonvensional, barang-barang tersebut berguna dalam meningkatkan kreativitas dan penanaman kepada anak mengenai kecintaan terhadap lingkungan atas pemanfaatan barangbarang yang tak terpakai.

Pada pelaksanaan kegiatan webinar, guru dan para calon guru melakukan praktik bermain alat musik menggunakan media barang-barang sederhana yang ada disekitarnya. Untuk teknik pukulannya, beberapa barang yang hampir memiliki karakteristik bunyi yang sejenis di kelompokkan. Seperti helm dan ember besar yang akan dianalogikan sebagai drum, dengan pukulan berdasarkan notasi sebagai berikut :

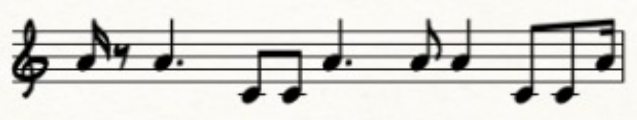

\section{Gambar 6. Notasi Musik Untuk Memainkan Ember Besar}

Untuk barang sejenis toples dimainkan dengan notasi sebagai berikut :

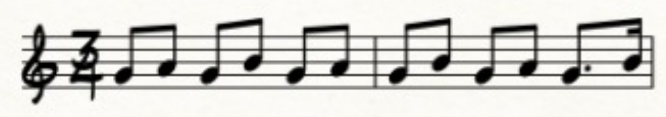

\section{Gambar 7. Notasi Musik Untuk Memainkan Toples}

Untuk barang sejenis mangkok, gelas, piring, botol dimainkan dengan notasi sebagai berikut :

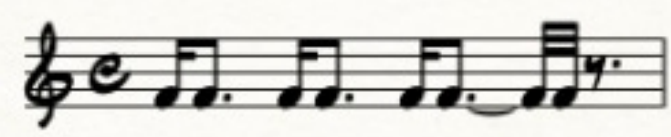

Gambar 8. Notasi Musik Untuk Memainkan Mangkok, Gelas dan Piring

Untuk sejenis kaleng dimainkan dengan notasi sebagai berikut :

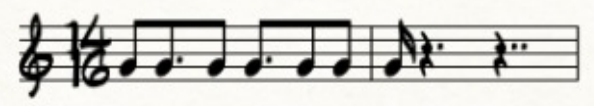

Gambar 9. Notasi Musik Memainkan Kaleng bekas

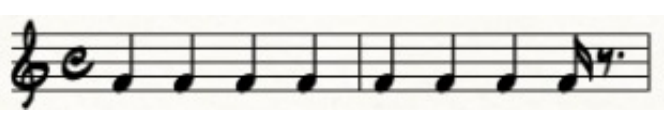


Gambar 10. Notasi Musik Untuk Memainkan Kaleng Kecil

Berdasarkan pemaparan dan proses praktik pelaksanaan belajar musik dengan menggunakan alat-alat sederhana terlihat bahwa belajar musik yang dilakukan bukan untuk menuntut peserta didik untuk bisa memainkan berbagai alat musik. Akan tetapi sebagai proses penanaman sense of music pada anak melalui pengalaman yang dimilikinya. Menurut Sukmayadi \& Purnama, (2016) setiap anak memiliki poteansi yang unggul dalam bidang seni musik yang dapat dikemangkan melalui pemanfaataan alat musik nonkonvensional yang difasilitasi oleh guru dalam menerapkan pembelajaran yang kreatif, produktif dan berkesinambungan.

\section{KESIMPULAN}

Belajar melalui musik dengan menggunakan metode Orff terfokus pada eksplorasi, imajinasi dan kreasi yang disesuaikan dengan kemampuan peserta didik anak usia dini. Berkaitan dengan hal tersebut sebagai guru maupun calon guru perlu memahami, menggunakan dan memanfaatkan barang-barang yang ada untuk dapat membentuk kreasi peserta didik. Berdasarkan penelitian yang dilakukan, para guru dan calon guru perlu menguasai lebih dalam mengenai metode Orff. Selain untuk dapat meningkatkan pengetahuan mereka hal tersebut juga perlu untuk diaplikasikan sehingga terbangun pembelajaran yang kreatif, inovatif dan menarik pada
Pendidikan Anak Usia Dini (PAUD) yang pastinya tetap disesuaikan dengan karakteristik anak.

\section{DAFTAR PUSTAKA}

Arwati, N. M., \& Fadillah, S. (2019). Pengaruh Gerakdan Lagu (Music And Movement)Terhadap Peningkatankosakata Bahasa Inggrispada Anak Usia 5-6 Tahun Di PAUD Kasih Ibu. PAUD Lectura Unilak, 5, 1-7. Https://Doi.Org/10.3969/J.Issn.100 0-7695.2019.05.001

Cary, D. G. (2012). Kodály And Orff: A Comparison Of Two Approaches In Early Music Education. ZKU Journal Of Social Sciences, 8(15), 180-194.

Fitroh, S., Fitroh, S. F., \& Khasanah, S. M. (2016). Musik Sebagai Stimulus Pada Kecerdasan Emosi Anak (Studi Kasus TK A Di Kelompok Bermain Kasih Ibu). Jurnal PG-PAUD Trunojoyo: Jurnal Pendidikan Dan Pembelajaran Anak Usia Dini, 3(1), 39-47. Https://Doi.Org/10.21107/Pgpaudtr unojoyo.V3i1.3483

Gustina, S. (2019). Pendekatan OrffSchulwerk Bagi Calon Guru Musik. 20(2), 96-107. Http://Journal.Isi.Ac.Id/Index.Php/ Resital/Article/View/2591

Halimah, L. (2016). Musik Dalam Pembelajaran. Eduhumaniora, 3(2), 54-67. Http://Repositorio.Unan.Edu.Ni/29 86/1/5624.Pdf

Idris, H. M. (2014). Meningkatkan Kecerdasan Anak Usia Dini Melalui Mendongeng. Luxima. 
Jamalus. (1988). Pengajaran Musik Melalui Pengalaman Musik. Depdikbud, Dirjen Dikti, PPLTK.

Kamtini, H. (2005). Bermain Gerak Dan Lagu Di Taman KanakKanak. Departemen Pendidikan Nasional.

Lestari, N. D. (2015). Penerapan Metode Carl Orff Untuk Pembelajaran Musik Dalam Drumband Sebagai Upaya Meningkatkan Keaktivan Dan Kreativitas Siswa Kelompok B Tk Sinar Melati Sleman.

Melalatoa, M. J. (1989). Pesan Budaya Dalam Kesenian. Berita Antropologi. JAFIS \& IP Universitas Indonesia.

Rizky, D., \& Putri, K. (2012). Pembelajaran Angklung Menggunakan Metode Belajar Sambil Bermain. Harmonia Journal Of Arts Research And Education, 12(2), 116-124. Https://Doi.Org/10.15294/Harmoni a.V12i2.2519

Sari, H., Sukmayadi, Y., \& Sandie, G. (2016). Pembelajaran Ritmik Melalui Media Alat Musik Berbasis Lingkungan Untuk Siswa Kelas Vi Di Sd Labschool Upi. Swara-Antologi Jurusan Pendidikan Seni Musik UPI, 4(2).

Solin, S. B., Masganti, \& Arlina. (2019). Pengaruh Bermain Drum Band Dari Bahan Bekas Terhadap Kecerdasan Musikal Anak Usia 56 Tahun. 07(01), 129-140. Https://Doi.Org/Http://Jurnaltarbiy ah.Uinsu.Ac.Id/Index.Php/Raudha h/Oai

Sukmayadi, Y., \& Purnama, A. (2016).
Model Pembelajaran Komposisi Musik Sekolah Melalui Pemanfaatan Perkakas Tangan. Resital: Jurnal Seni Pertunjukan, 17(3), 158-169. Https://Doi.Org/10.24821/Resital. V17i3.2225

Sumaryanto F., T., \& Utomo, U. (2015). Forms, Development And The Application Of Music Media In The Kindergartens: A Comparative Study Of Two Kindergartens. Harmonia: Journal Of Arts Research And Education, 15(2), 101-106.

Https://Doi.Org/10.15294/Harmoni a.V15i2.4099

Udi Utomo. (2004). Pembelajaran Musik Di Taman Kanak-Kanak. Harmonia - Jurnal Pengetahuan Dan Pemikiran Seni, 1-14. Https://Doi.Org/10.15294/Harmoni a.V5i3.824

Ulucay, T. (2019). A Research On The Art Needs Of Music Teacher Candidates. Universal Journal of Educational Research, 7(4), 923928.

Https://Doi.Org/10.13189/Ujer.201 9.070402

Wadiyo, W. (2015). Music As An Integrated Education Tool For Preschool Students. Harmonia: Journal Of Arts Research And Education, 15(2), 144-151. Https://Doi.Org/10.15294/Harmoni a.V15i2.4691

Wadiyo, Wadiyo, \& Haryono, S. (2016). Uji Coba Produk Lagu Anak-Anak Bertema Pendidikan. Resital: Jurnal Seni Pertunjukan, 17(3), 170-177. Https://Doi.Org/10.24821/Resital. 


\section{V17i3.2226}

Wadiyo, Wadiyo, \& Utomo, U. (2018). Pengembangan Materi Ajar Seni Budaya Sub Materi Musik Pada Sekolah Umum Jenjang Pendidikan Dasar. Resital: Jurnal Seni Pertunjukan, 17(2), 87-97. Https://Doi.Org/10.24821/Resital. V17i2.2221

Wicaksono, R. Y., \& Utomo, U. (2017). Daya Tarik Lagu Bagi Anak Usia Dini : Studi Kasus Di TK Pertiwi I Singodutan, Wonogiri. Jurnal Seni Musik, 6(2), 91-93. Https://Doi.Org/10.15294/Jsm.V8i 2.32610
Yetti, E., \& Khairiah, I. (2017). Peningkatan Kemampuan Musikalitas Melalui Bermain Alat Musik Dol. Jurnal Pendidikan Usia DinI, 11(2). Https://Doi.Org/Https://Doi.Org/10 $.21009 /$ JPUD. 112.03

Yosep, W. (2004). Pembelajaran Musik Kreatif Pada Anak Usia Dini (The Learning Of Creative Music In Early-Childhood Children). Harmonia - Journal Of Arts Research And Education, 5(1). Https://Doi.Org/10.15294/Harmoni a.V5i1.829 